CORRECTION

https://doi.org/10.1038/s41586-019-1298-9

\title{
Author Correction: Forearc carbon sink reduces long-term volatile recycling into the mantle
}

P. H. Barry, J. M. de Moor, D. Giovannelli, M. Schrenk, D. R. Hummer, T. Lopez, C. A. Pratt, Y. Alpízar Segura, A. Battaglia, P. Beaudry, G. Bini, M. Cascante, G. d'Errico, M. di Carlo, D. Fattorini, K. Fullerton, E. Gazel, G. González, S. A. Halldórsson, K. Iacovino, J. T. Kulongoski, E. Manini, M. Martínez, H. Miller, M. Nakagawa, S. Ono, S. Patwardhan, C. J. Ramírez, F. Regoli, F. Smedile, S. Turner, C. Vetriani, M. Yücel, C. J. Ballentine, T. P. Fischer, D. R. Hilton \& K. G. Lloyd

Correction to: Nature https://doi.org/10.1038/s41586-019-1131-5, published online 24 April 2019.

In this Article, the original affiliation 2 (California Water Science Center, USGS, San Diego, CA, USA), associated with authors P. H. Barry and J. T. Kulongoski, was not applicable because the study was not directly funded or approved by the United States Geological Survey (USGS). This affiliation has been removed and all subsequent affiliations have been renumbered accordingly. In addition, in the Acknowledgements, the surname of J. Labidi was misspelled 'Libidi', and the following statement should have been present: "J.M.d.M. acknowledges funding from Universidad Nacional Costa Rica, the World Bank, and the Costa Rican Ley Transitorio 8933 used to acquire a laser carbon isotope system in collaboration with R. Sánchez-Murillo and G. Esquivel-Hernandez". The Article has been corrected online. 